\title{
Comparing Industrial Cluster Cases to Define Upgrade Business Models for a Circular Economy
}

\author{
Magnus Simons
}

\begin{abstract}
Upgrading is often seen as a means to strengthen customer loyalty between investments in new equipment, but there is more to it. It is a means to introduce innovation in small, but continuous steps keeping both OEMs and their customers at the innovative forefront of technical and business development. Upgrading also improves sustainability and it is a driver in the development of the circular economy. Basically upgrading means transformation of a used piece of capital-intensive equipment to meet the new conditions in the user's business environment, but in practice it can take on a variety of forms depending on what type of added value is provided to the customer. In this article, we define four generic types of upgrade business models based on the industrial cluster cases in the UIW-project. Using a modified business canvas approach, we define the four Upgrade business models and compare how they create value for the customers, how they organise their main activities and how they earn money. A central means of achieving profitable upgrade business is to develop efficient business processes through digitalisation and through the use of modern information technology. Here we identify four areas where technologies such as AR and VR help to create an efficient environment for information management and communication in the upgrade value network.
\end{abstract}

Keywords Upgrading - Business model - Digitalization - Information technology - Value proposition - Value network - Earnings logic • Business process • Circular economy

M. Simons ( $\square)$

VTT Technical Research Centre of Finland Ltd., Espoo, Finland

e-mail: magnus.simons@vtt.fi

(C) The Author(s) 2017 


\section{Introduction}

Upgrade is a life cycle service provided to an owner or user of capital-intensive equipment. As such it is one type of service product in a larger service portfolio provided during the life cycle of the equipment in order to enhance its performance. We define commercial upgrade service provided to a customer here as upgrade business. As a business model, the upgrade service differs in many aspects from services like spare part sales or maintenance. To put this new business model into context, we will first have a look at the concepts of circular economy and industrial service business.

Circular economy and industrial service business are slowly becoming common concepts in industry. They are, however, not new as concepts (Roos and Agarwal 2015), but as more and more efforts are put into this area, both by industry and academia, the terminology gets more vivid and the concepts get more comprehensive. In order to understand the role of upgrade business in industry, we start by identifying its context.

Circular economy and industrial service business are interrelated concepts (Roos and Agarwal 2015). However, they represent slightly different views on the same topic. While the concept of a circular economy starts at a system-level view on the industrial ecosystem (Stahel 2016) and material flows (Ellen MacArthur Foundation 2016), industrial service business takes the view of the company. The driver behind the circular economy is to achieve an ideal state resembling nature, where internal cycling of material is complete or nearly complete (Bocken et al. 2016).

Several authors have described business models for combining the drivers of the circular economy with the drivers of single companies (Allwood et al. 2011; Ellen MacArthur Foundation 2016; Bocken et al. 2016; Lacy and Rutqvist 2015). According to Bocken et al. (2016), two major strategies for building circular economy business models can be identified: (1) closing the resource loops, and (2) slowing the resource loops. The Ellen MacArthur Foundation (2016) has distinguished between finite stock and renewable material. They identify several strategies for prolonging these loops. From the Use-it-Wisely (UIW) point of view the finite material cycles are more relevant. Here the economic circles described by the Ellen MacArthur Foundation are to maintain/prolong, reuse/redistribute, share, refurbish/remanufacture and to recycle the finite materials.

Linton and Jayaraman (2005) have focused on different business models (modes) of product life extension for finite materials. The nine business models they have identified and their main focus or objective can be seen in Table 1. In this chapter, we will focus on upgrade, part reuse and remanufacturing which are closest to the cluster cases in the UIW-project.

Business models like recall, repair and maintenance strive to ensure that the delivered products provide the user with the physical and functional qualities they originally invested in as they bought the product. Through these business models the customer can expect to make continuous use of the product over its life time. But these models do not improve on the qualities of the product as technological 
Table 1 Business models for product life extension (adopted from Linton and Jayaraman 2005, p. 1808)

\begin{tabular}{l|l}
\hline $\begin{array}{l}\text { Business models (modes) for product life } \\
\text { extension }\end{array}$ & Focus \\
\hline Recall & Safety and extend life \\
\hline Repair & Life extension \\
\hline Preventative maintenance & Continuous use \\
\hline Predictive maintenance & Life extension \\
\hline Upgrade & Reduce cost and extend life \\
\hline Product reuse & Life extension \\
\hline Remanufacture & Life extension \\
\hline Part reuse & $\begin{array}{l}\text { Reduction of materials and processing } \\
\text { inputs }\end{array}$ \\
\hline Recycle & Reduce material and energy inputs \\
\hline
\end{tabular}

development proceeds and, thus, they will not impact the competitive value of a product in comparison to other newer ones. This is the value added upgrade that business is focusing on and, hence, the way to differentiate from other service business models. Product reuse means transferring a product from one owner to another as it gets obsolete to the first one. Recycling is the re-use of materials in a product. This can be seen as the prevailing industrial practice for handling finite materials.

According to Linton and Jayaraman (2005), an upgrade improves the quality, value, effectiveness or performance of a product which has eroded over time as competitors bring new technologies to the market. "Very complex products may also contain components or subsystems with far shorter life-cycles than the product" (Linton and Jayaraman 2005, p. 1814). An upgrade may be conducted by the customer, manufacturer or a third-party vendor. Parts required for an upgrade are typically provided by the manufacturer or a third party. Upgrade involves moderate transformation of the unit. The information value is high, since the product life and/or capabilities are extended with only small amounts of material and labour.

Remanufacture is, by Linton and Jayaraman (2005) defined as the restoration of a used product to a condition close to that of a new one. The restored product "provides the performance characteristics and durability as least as good as the original product" (Linton and Jayaraman 2005, p. 1815). Remanufacture involves a major transformation of a unit, component or part. The value of added material is low, since few new parts are used, but the labour value added is high, since many parts may have to be tested and/or refurbished. Although much of the labour value-added is of a low skill level, low labour costs are an important element for the economic viability of this approach.

Part reuse is defined, by Linton and Jayaraman (2005), as "the use of a part in its same form for the same use without remanufacturing" (Linton and Jayaraman 2005, p. 1815). "The cost of collecting and testing the parts is much less than the cost of 
manufacturing new parts. Reuse of parts involves a major transformation of the product. It involves the extraction of the desired components from the product. The components may need to be tested and/or refurbished. The information value of this mode is medium, since knowledge of the product and the reuse requirements for the component is required. The material value added of the reuse of parts is high, since the component not only offers the correct material composition, but also the desired shape. The labour value is low, since like many of the other modes, it typically focuses on placement and extraction of the component" (Linton and Jayaraman 2005, p. 1816).

These business models for product life extension, described by Linton and Jayaraman (2005), focus on how to prolong the life span of the product and on what actions the extension will require. Other writers have also included other aspects in the business models. Lacy and Rutqvist (2015) also include the aspect of ownership of products, components and materials in their models. They describe five potential business models related to the circular economy. These business models are:

- Circular Supply-Chain - access to fully renewable, recyclable or biodegradable inputs

- The Product Life-Extension Business Model—making a product's useful life as long as possible and maximised profitability over the lifecycle

- Recovery and Recycling - every by-product and waste stream is optimised to maximise its revenue potential

- The Sharing Platform Business Model—provides a platform to connect product owners with individuals or organisations that would like to use them

- The Product as a Service Business Model - selling access to - and the performance of — an item on either a short or long-term basis.

In the UIW-project, we have focused on the upgrade of durable goods, which in traditional transaction based business models require big upfront investment. In this chapter, we will examine the experiences from the six industrial cluster cases in the UIW-project. Although most of them were at a very early phase of upgrade business development, each cluster had a shared vision of what kind of business activities they were aiming at. We will see from these cases how they consider closing the loops, prolonging the loops or how ownership of the durable goods could affect the business models for upgrading of them.

\section{Upgrade Business Models}

In this chapter we analyse the business models explored by the six cluster cases of the UIW-project in order to get a more detailed understanding of how these models work, what the drivers of these models are and what challenges related to these business models were identified during the research project. To compare the business models of the cluster cases, we used a simplified version of the business 
model canvas developed by Osterwalder and Pigneur (2010). We focus our analysis on the value proposition, the main resources and value network, the earnings logic of the business models used in the cluster cases and on the information management in main business processes. The analysis also raises the question of how the main actors in the value network have to transform their business model to create synergy between original equipment production and upgrading. In the next section we look at how upgrade processes can be made more efficient through the use of modern information technology.

The value proposition to the customer is a central part of the business model. It tells us what added value our service offering can provide to the customer. In the case of capital intensive equipment and machinery, the value of additional after-sales services is related to the use of this equipment. In an industrial business-to-business situation, a basic value for the customer is return on investment - invested capital should be used as profitably as possible over the span of the life cycle of the equipment. In practice, this can mean different things in different situations.

In the upgrade value networks, we can identify a set of basic roles occurring in slightly different ways in the different clusters. These are the user of the equipment, the main designer, the producer or provider of the equipment-here called the original equipment manufacturer (OEM), the upgrade service provider and provider of supporting services. The UIW-clusters are at an early stage of development of upgrade business and in most clusters, the final operational organisation has not yet been set up. Yet, from the organisation of the cluster cases we can see which actors the core companies in the clusters have identified as central partners and resources in their upgrade network.

Based on the cluster cases, we can say that the main earnings logic of the companies involved in upgrading is to improve their competitive situation and to earn more through improvement of added value for the customers. In most cases, upgrade business is focusing on and improving on already existing customer relationships. Upgrading can, however, also bring new customers through the added value of the upgrade service. To understand how the cluster cases aim to profit from the new upgrade services, we look at how this new service increases sales directly through sales of innovative upgrade services or indirectly through improved customer loyalty, and how costs are managed through the introduction of efficient service processes supported by new innovative digital information management solutions.

In the upgrade business, many business processes differ from processes used in original equipment manufacturing. There are also completely new processes like the reverse logistics process in remanufacturing. For many of these processes, a central feature is low volume and little repetition, customisation and a whole lot of information to be managed. In the UIW-project focus was on information management issues. We will in this chapter look in more detail at how this issue was met in the business models explored during the UIW-project.

Based on analysis of the cluster cases in the UIW-project, we can distinguish between four generic upgrade business models among the six clusters. We call 
these the Customized Upgrade, the Modular Upgrade, the Remanufacturing and the Service Upgrade business models. These models differ in the type of added value with which the customer is provided, but also in how this value is produced. Our study also shows that the different business models stress the need for development of digital means in different areas.

\subsection{Customised Upgrade}

The first business model is the Customized Upgrade. This model is based on the experiences from Clusters \#3 and \#5-the Italian and Greek the clusters (see Chapters "Space Systems Development" and "Supporting the Small-to-Medium Vessel Industry") in the UIW-project. Here the provider of a capital intensive physical product provides services aimed at upgrading the performance of the product, owned and used by an external customer, to meet new requirement from the customer or user of the equipment. In this business model, the service is initiated by the need of a specific customer and the service is customised to meet these needs. Central challenges in this business model are identification and management of customer needs in all phases of the service process, and to manage cost and time of the customised service performance.

\subsubsection{Value Proposition for Customised Upgrade}

In the Customised Upgrade business model, the proposition made to the customer is to adapt the original equipment to new needs of the customer. These needs may occur due to changes in the business environment of the customer, like new needs of the customer's customers or changes in equipment and services provided by competition.

Cluster \#3 is looking at developing a new business model providing space services, using the Space Tug concept as an example in the project. A space tug is a type of spacecraft used to transfer payloads between orbits or to escape trajectory. Thales Alenia Space is studying this concept and related technological research in a parallel project (Pasquinelli et al. 2016). This was felt as the best disruptive example to study the UIW-methodology with respect to a new type of business. Moreover, it is a good example in the space domain where there is not a final customer who buys a spacecraft and related services, but there are multiple potential customers who can profit from a multi-mission spacecraft. This example is very complex, and the methodology may also be applied to conventional programs (institutional or commercial). In case of Cluster \#5, customers are provided the opportunity to adapt the vessel from one type of shipping business into another as market demand shifts. Requirements for the new business activities are defined with the customers and they are implemented through technical or other changes to the vessel. Improved sustainability of the vessel is often an objective for the upgrade. 
In Cluster \#5, the aim is to upgrade the vessel according the needs of the owner. As market focus shifts from one segment to another, the vessel has to be adjusted to meet the requirements in the new market segment. This process also involves having the classification of the vessel checked and perhaps changed.

\subsubsection{Roles in Customised Upgrade}

In Customised Upgrade, the key players are the owner of the equipment and the OEM responsible for production of the original equipment. The customer initiates the upgrade process by presenting new needs and the OEM is responsible for providing the upgrade service. Due to the complexity of the customised upgrade process and the information management involved, the main roles like customer needs management, upgrade engineering and manufacturing are typically managed internally by the OEM. Supporting functions can be outsourced to expert organisations.

In both Clusters \#3 and \#5, the OEM is responsible for a majority of the roles involved. They are the provider of the solution, engineer, part or component manufacturer as well as coordinator of the final integration as part of the upgrade service. In Cluster \#3, the responsibility for managing information related to the customer request is outsourced to Vastalla - a company offering IT consulting services, software development and IT systems activities emphasising especially on IT security. In Cluster \#5, the boat manufacturing company OCEAN acts as both original equipment producer and as provider and producer of the upgrade service. Here the non-governmental ship classification society INSB, responsible for ship classification, survey and statutory certification and engineering approvals is a central actor in the value network. It plays an important role in the approval of the new, upgraded vessel construction, and it is involved as a partner in the early phase of the upgrade process.

Based on these two cluster cases, we suggest that in Customised Upgrade the control of the information flow requires the OEM to take a central role in the operative work. The mode of operation is vertically integrated, leaving only support functions and specialist functions to outside partners. Innovative development of core technology to support the upgrade business is done in a close network of partners (Fig. 1).

\subsubsection{Earnings Logic in Customised Upgrade}

Offering a customised upgrade requires unique input from the service provider and it is typically done at a high cost level. Due to this customised upgrades can only be offered if the price of the service is high enough or the costs can be returned otherwise. Then again, a high price requires high added value to the customer. This is typically achieved through the provision of unique service characteristics provided only to the customer in question. This can be seen in the case of Cluster \#3, 


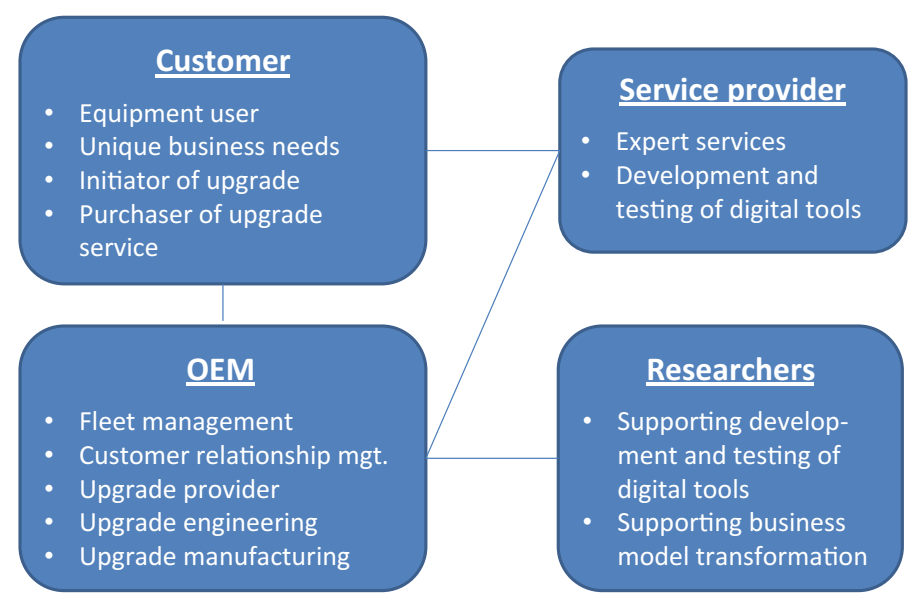

Fig. 1 Actors, roles and connections in the Customised Upgrade business model in the UIW-project

where the goal is to present a totally new, unique value adding service to the customer or user of the space equipment. Changing the use of a space unit in orbit was earlier done from a space shuttle, but today there is no infrastructure available for this task.

In Cluster \#5, the upgrade service is aiming to transform the vessel from use in one business area to another. This can be profitable to both customer and service provider as long as the upgrade service is less expensive than options like buying a new vessel, but still the price is high enough to give the provider a good margin. Limited and less profitable customisations can be done, for instance, for the sake of customer loyalty.

Customised upgrade involves some extent of disassembly and reconfiguration of the existing equipment. In some cases this is done in the field, in other it is done at a factory. Since this involves activities not part of the original equipment manufacturing, it is likely to require some extent of dedicated resources, infrastructure and facilities. Since customised upgrade is based on initiatives from the customer, information management is crucial for cost management. Also management of critical skills and functions is likely to require in-house resources.

\subsubsection{Information Management in Customized Upgrade}

In Customised Upgrade, a major challenge in the actor network is the collection and management of customer-specific information. Customisation means deviations from standards and from previous activities, which again means that existing data and information is no longer up-to-date. Instead, customisation requires specification, documentation and management of new information. Since the generation of 
new data and information is a manual and often not a well-structured task, it is prone to mistakes and delays. Checking that all necessary information exists and is available is a major challenge in customisation. This is also true for the quality checking and the dissemination of correct and up-to-date data and information to all parties concerned. These challenges are reflected in the pilots made in Clusters \#3 and \#5.

Cluster \#3 developed a system to enhance communication between stakeholders (including customers) in all communication-sensitive phases of the service lifecycle, from initial choice among design solutions, to choice among alternative configurations before service executions also supporting general decision-making processes during Space TUG operations. This cluster focused on developing a reference data model (meta-model) that can serve as standard for storing and interchanging industrial information. Cluster \#3 is also developing a Web Configurator to enhance communication between stakeholders in the service lifecycle, modelling the application using the meta-model that makes use of software called the Web Environment.

Cluster \#5 developed a system to support upgrades of small passenger boats. The upgrades can be driven by changes to regulation or variation in service demand, which have to be balanced with reductions in cost and lead-time of product modifications. Within UIW, Cluster \#5 developed an information system to support upgrading activities in this context, through giving stakeholders access to an information-rich technical metafile for the vessel that includes all aspects of the vessel. The meta-file is accompanied by a vessel web configurator that is the customer's entry tool to the application suite of Cluster 5.

\subsection{Modular Upgrade}

The second business model, used in the Finnish Cluster \#2 (see Chapter "Rock Crusher Upgrade Business from a PLM Perspective"), we call Modular Upgrade. As in the previous business model also in this model, the OEM of a capital intensive physical product provides services aimed at upgrading the performance of the equipment, owned and used by an external customer. In this business model, the service is not defined by the needs of a single customer or end user. In this business model, the service provider defines the characteristics of the upgrade based on input from the market. In the Finnish case, the upgrades are changes to the physical machine predefined by the product development in the OEM. A modular structure of the machine enables the company to develop the features of the machines piece by piece. As the new modules are fitted to old machine constructions, they become upgrade options for the fleet of machines in use in the field. 


\subsubsection{Value Proposition for Modular Upgrade}

In this business model, the upgrade service is predetermined by the service provider. Equipment owners or users are provided leading edge performance through predefined and productised modular upgrading of their equipment. Increased sustainability in use of original equipment can be part of added customer value. The added value depends on how the customer can utilise it in order to increase competitiveness or to move into new areas of business. In Cluster \#2 crushers are, for instance, adapted for use in urban areas through additions of noise and dust-reducing modules. This gives the operator of the crusher improved opportunity to compete for sustainable urban crushing contracts.

\subsubsection{Roles in Modular Upgrade}

In Modular Upgrade the OEM plays a central role as the provider of the upgrade service to the owner or user of the original equipment. The OEM also takes the responsibility for the defining and engineering of the upgrade module. Modular upgrade sets the emphasis of efficiency of operative execution and thus requires specialised resources. A forward integrated role of the OEM creates a close relationship to the end users and customers, and through a thorough productisation of the upgrade service, operative functions like module production, customer interface design and production, and final assembly can be outsourced to a network of specialised actors.

In Cluster \#2, Metso - the OEM-is concentrates on designing the modular upgrades based on thorough understanding of the technology and the market needs. The operative responsibilities for producing the upgrade service can be outsourced to a partner company. Since the modular upgrade, projects are limited in scope, they are not always suitable for the business processes of the OEM or for the organisations focusing on these processes. This is why Metso is considering outsourcing the production of the upgrade service to an external company such as RD Velho-a smaller and more agile partner organisation.

In the Cluster \#2 case example, part of the operative information management is also outsourced to the network partner. In this case, RD Velho is responsible for collecting information on the machine as it is used in the field. This information is compared to the original geometry of the machine and to the geometry of the upgrade module to see how it can be fitted to the machine (Fig. 2).

\subsubsection{Earnings Logic in Modular Upgrade}

The Modular Upgrade business model strives to provide the customer with new, but not unique, functionality in order to improve customer competitiveness. Restricting the upgrade to single modules in the equipment limits both the effect on the performance improvement, but also the resources needed for performing the upgrade. 


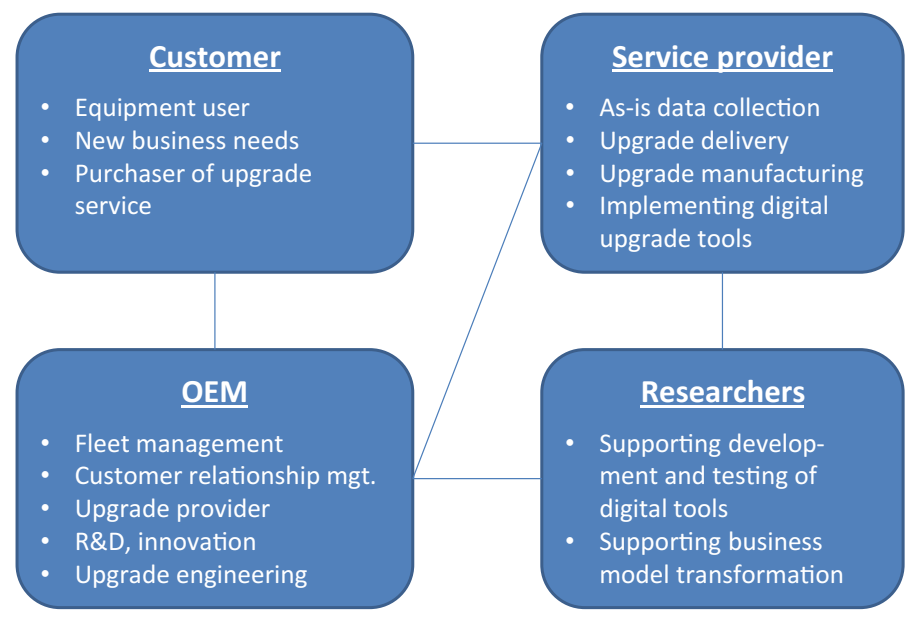

Fig. 2 Actors, roles and connections in the Modular Upgrade business model in the UIW-project

Basing the upgrade on design and plans from product development ensures that the efforts put on developing the module are re-used both in new products and in upgrades for other customers.

The modular design also means that the production of the physical module and its parts is repeated. This makes batch production possible and enables economies of scale in production of the modules. The experience from Cluster \#2 shows however that the upgrade business is in many other areas quite different from the original equipment manufacturing and can benefit from separation between the two business models. For instance, the management of a modular upgrade project is much more limited than the management of an original equipment project. Also assembly of the module to a machine in the field differs significantly form new equipment production in the factory. Here, dedicated upgrade resources-in-house or external - can be necessary.

In the case of Cluster \#2, an upgrading business already exists, but to improve profitability of this activity, a new mode of upgrade business is developed. In the new mode, the modular upgrade business model, Metso is to some extent reducing the customers' options from a completely customer needs-based mode to a modular, innovation-based mode. They are balancing added customer value with internal efficiency, cost, control and profitability.

\subsubsection{Information Management in Modular Upgrade}

In Modular Upgrade the challenges in information management are reduced significantly compared to the Customised Upgrade. Since it is a major part of development work and thus, also of information management, it is handled in-house in the OEM's product development organisation, the main information 
management challenges are related to what goes on outside this organisation. A major information challenge is to collect and keep up to date on what is happening to the fleet of equipment in use in the field. Machines change owners and they are transferred from one location to another. At the same time they are maintained, changed or upgraded by their owners or by third parties. Defining the interface between the upgrade modules and the equipment in the field can be considered a bottleneck of information management in this type of business model.

In Cluster \#2, where Metso is already providing customised upgrades, the aim of the development process in the UIW-project was to improve profitability of this business. A central objective was to build and develop a dedicated business network to perform the upgrade activities. Presently, Metso designers and workshop personnel do upgrade activities in parallel with the development and production of new machines. Since the upgrades are generally small, unique projects, they are difficult to fit into the main activities. In the UIW-project, the role of the upgrade producer has been planned for RD Velho - today a subcontractor in engineering to Metso. This organisation can in the future be responsible for module interface design activities, and of the coordination of partial production and installation of upgrade modules. Through the support of an outside partner, Metso can free their own resources to focus on the main business.

Cluster \#2 has in the UIW-project-tested 3D scanning technologies for creating digital data and information about the target machine including 3D geometry. This was used especially to document changes made to the machine during use. A central objective of creating new information about the machine is to enable fast design of the interface between the upgrade module designed by Metso and the machine in operation. Having complete information on the state of the machine during upgrade design, enables a fast upgrading process, especially when the upgrading is taking place in the field where the machine is used. Cluster \#2 also tested VR- and AR-based review tools to envision upgrade solutions to engineers and customers. These tools were tested in design reviews with Metso engineers. The design object used in the test was a maintenance platform attached to a mobile rock crushing machine that was part of the upgrade for the already existing machine. The virtual reviews enable engineers to evaluate upgrade solutions before they are realised as physical elements of the upgrade module. This reduces the need for iterative behaviour in downstream functions like purchasing, component manufacturing, upgrade assembly and installation.

\subsection{Remanufacturing}

The third business model we call Remanufacturing. This business model has close resemblance to what Linton and Jayaraman (2005) call remanufacture, but it also has elements of the part reuse model. In this business model original equipment is disassembled into parts which are re-used in the production of new equipment. The new equipment can fulfil the same or similar functions as the original equipment, or 
it can have completely new functionality. A main objective of reusing parts is to create a sustainably produced piece of equipment through reduced use of material and energy resources in the production of the new equipment.

In the Dutch case, Cluster \#6 (see Chapter "Sustainable Furniture that Grows with End-Users"), the core company is collecting furniture sold to external customers in order to re-introduce them as parts of new furniture. Collecting of furniture can either mean that the parts are bought back from customers willing to get rid of old furniture and selling upgraded furniture to new or repeat customers, or it can mean that the equipment is leased to the customer and parts of the old equipment are used as input for new equipment, thus reducing the cost of materials in the new delivery.

\subsubsection{Value Proposition for Remanufacturing}

Remanufacturing is typically driven by the values of the end user and by the OEM. The value proposition to the customer or end user of equipment is that sustainable and ecological values are endorsed in the production of the new equipment through prolonging of the life cycle of parts of the equipment. Hence, the material loops are secured through collaboration benefiting both the end user and the OEM.

In Cluster \#6, the Dutch company Gispen is adding new customer value through sustainably remanufactured furniture. They provide the users new furniture, and at the same time they add new ecological value for the customer as they build the furniture from used parts, thus reducing the need for use of materials and energy in production.

\subsubsection{Roles in Remanufacturing}

In Remanufacturing, the OEM is typically in a central position. It manages the equipment design and business, and it has control of what parts have been used in what products and of the design and production information of these parts. In this position, it can be well positioned to also be a provider of remanufactured equipment. Forward integration for better control of the equipment fleet will for many OEMs become a necessity as they go into this area of business. Remanufacturing also involves other processes that are not needed in original equipment manufacturing. These are for instance, reverse logistics, disassembly of the original equipment and quality checking of reusable parts. These processes can be outsourced to dedicated expert organisations.

In Cluster \#6, the OEM-Gispen-looked into the Remanufacturing model in order to gain insight in the effects and requirements for changing business. Close contact to the customers is crucial in order to tailor furniture to customer needs and in order to manage the fleet of furniture in use. This will also require management of a totally new operation like reverse logistics, the disassembly of old furniture and the quality control of used parts. Where the scale and duration is different between 
the OEM and the upgrade process, it is natural to look for new ways to organise the activities and sometimes this mean involving external partners to perform tasks and activities not suitable for own processes and organisation.

In the different scenarios explored in the UIW-project, Gispen is considering several alternatives for management of ownership of the furniture and components. One way is to buy back used furniture; another is to own the furniture and lease it to the user.

In Cluster \#6, Gispen has chosen to cooperate mainly with the research organisation providing support in defining and analysing the new business model (Fig. 3).

\subsubsection{Earnings Logic in Remanufacturing}

The earnings logic of remanufacturing rests on the values of the customer. In remanufacturing, a product is produced through the reuse of parts, thus reducing the use of virgin materials and energy to form a new part. Often, but not always, this is lower than the price for new products. Since the reuse of parts involves reverse logistics, disassembly of the used product, and quality control, the production of the remanufactured part includes additional costs not included in the production of original parts. In Cluster \#6 Gispen is providing the end user a new offeringsustainably produced furniture. This can be seen as an addition to their existing product portfolio.

As mentioned before, remanufacturing requires a whole range of new activities including management of the use base, logistics for the collection of used products, disassembly and so forth. This will require a dedicated workforce and infrastructure capable of performing at high productivity and low costs.

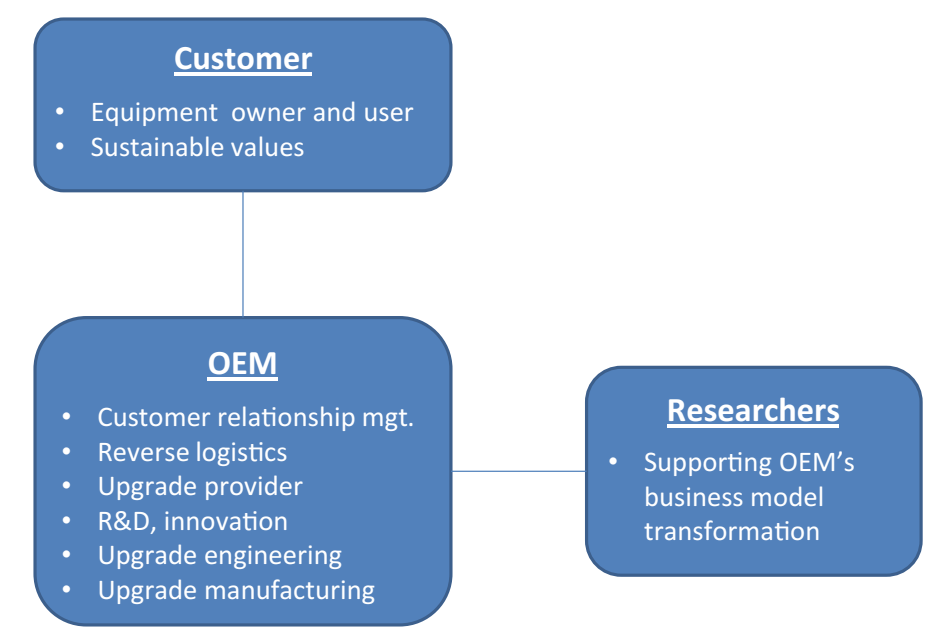

Fig. 3 Actors, roles and connections in the Remanufacturing business model in the UIW-project 
A central challenge in remanufacturing is the management of the installed base. How can the service provider ensure that used parts are available as they are needed in the process of remanufacturing? One option for the service provider is to keep the possession of the goods and only rent or lease it to the user (see Lacy and Rutqvist 2015). This business model, however, also includes challenges. In Chapter Sustainable Furniture that Grows with End-Users, a scenario based on leasing of the furniture to the users, showed that a long usage cycles generates long delays with respect to cash flows for the provider and producer of the remanufactured product.

\subsubsection{Information Management in Remanufacturing}

As in most areas of the circular economy, a central idea of Remanufacturing is to ensure that efforts and materials included in an existing machine or equipment are used and reused as much as possible in order to reduce creation of waste and use of energy. This is a primary driver behind remanufacturing. Reusing components of equipment provides the customer with an ecologically more sustainable product, but productivity and profitability in this business requires strict control of both the flow of material and of information.

Cluster \#6 focused on the development of a circular economy design strategy. To do this, the cluster developed tools and methods that speed up and improve the efficiency of the design information flow in the communication between customers, manufacturers and designers to design, upgrade and reuse products according to circular economy principles. In the UIW-project, Cluster 6 evaluated a Design Framework, a checklist approach to circular product design using a recently developed lifecycle analysis tool (LCA+) for circular economy scenarios. The aim of the task was to describe the development of a lifecycle analysis tool (LCA) and evaluate the usefulness of this tool.

\subsection{Service Upgrade}

The fourth business model is called Service Upgrade. Here new, innovative digital tools are introduced as part of a service in order to radically improve the added value provided for the customer. Using new, innovative digital solutions, the customer is offered an information service, which significantly improves critical business processes and the use of capital intensive equipment. This model offers unique business opportunities for service providers. This can, for instance, be a service supporting other upgrade activities either in-house or as a service to external customers. In the Swedish Cluster \#4 (see Chapter "Adaptation of High-Variant Automotive Production System Using a Collaborative Approach"), the owner of the production equipment is planning and performing the upgrade of the equipment themselves. The original provider of the equipment can be involved in this process, but this varies from case to case. Services are also procured from outside service 
providers, but the main responsibility for the upgrade is with the owner. In the Spanish cluster-Cluster \#1 (see Chapter "Collaborative Management of Inspection Results in Power Plant Turbines")—a service provider is improving its capabilities to provide a service to an external customer who owns the capital-intensive equipment. The information provided through the service can be used by the owner to maintain the equipment or as input for planning an upgrade to meet new needs.

\subsubsection{Value Proposition for Service Upgrade}

The value for the customer in the Service Upgrade business model is the improved efficiency of service provision and more valuable results.

Cluster \#1 is striving to improve service performance in the turbine inspection process. Through the improved service, the customer gets better information on the condition of the equipment and can make better decisions on how to operate and maintain the equipment.

In Cluster \#4 the production line for trucks is adapted to changed market needs. The changing demand for different types of trucks requires changes in technology and in layout in the production line. Another example of adopting to change market needs is when new legislation forces users of stone crushers to improve the safety of the operator to meet the new standards. The upgrade necessary to do this can be added as a module to the machine operating in the field.

\subsubsection{Roles in Service Upgrade}

In Service Upgrade, the focus is on the network actors providing services to the equipment owners.

In Cluster \#1, the service providers are not providers of the original equipment, but specialise in providing high level, focused service for a specific market segment. The competitive edge for this company is based on managing the service task. In Cluster \#4, where the customer is internal, the service provider is not the producer of the original equipment, but the service provider has been involved in designing and building the manufacturing system, and thus also has a thorough understanding of the system and its components. In both clusters outside research partners were involved in the development of new tools and technology for improving the service operation.

In the Service Upgrade the OEM of the equipment in use is not directly involved in the service, but the core actor in this value chain providing the service to the end user is the service provider. This actor is responsible for both planning and executing the service. External actors like research partners support the development of service technology (Fig. 4). 


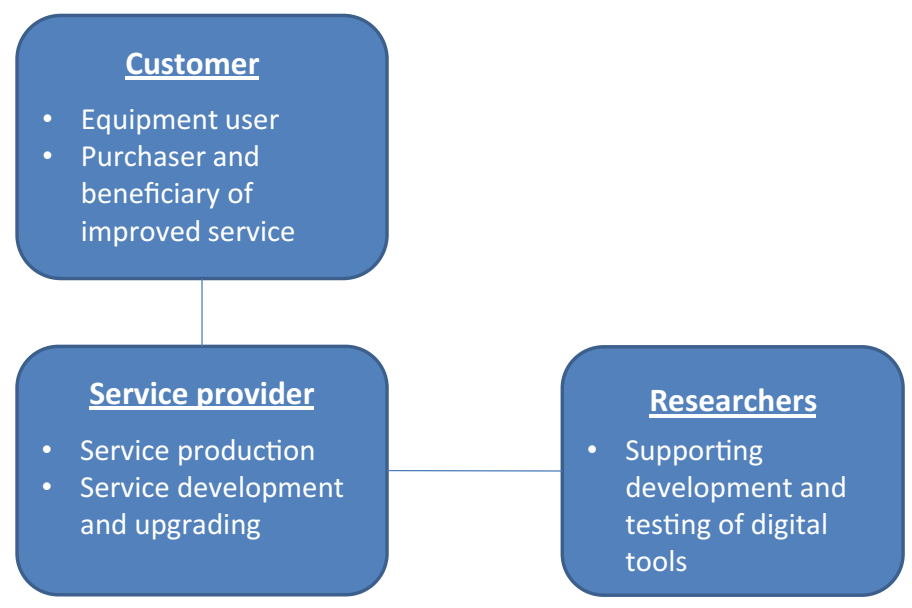

Fig. 4 Actors, roles and connections in the Service Upgrade business model in the UIW-project

\subsubsection{Earnings Logic in Service Upgrade}

In the Service Upgrade business model, the objective is to improve an existing service in order to improve customer value or to improve the efficiency of the service process. The first option will offer an opportunity to distinguish from competition and to charge a higher price for the service. The second option cuts cost for the service provider.

In Cluster \#1, Tecnatom focuses on improving internal processes in order to meet the needs, not of a specific customer, but of the market as a whole. The new solution developed and piloted in the UIW-project enables Tecnatom to provide the customer more elaborate information on the condition of the power plant's equipment. This enables better and faster understanding for the customer of what has been done during maintenance and what still required.

In Cluster \#4 information on the state of the Volvo production plant is collected through scanning. This enables efficient planning for upgrading the process to meet the new market needs.

\subsubsection{Information Management in Service Upgrade}

In Service Upgrade, a central objective is improving the value added provided by the service to the customer. This added value can be achieved through new digital means for creation of data or from new means to combine and bundle data to useful information, thus, making it easier for the customer to acquire and use the information. This can be seen in the pilots developed in Clusters \#1 and \#4.

Cluster \#1 developed value-added turbine inspection services for the fossil power industries. The aim was to develop collaborative environments that make all 
available and relevant information accessible to all stakeholders taking part in the post-inspection decision-making processes. The ultimate goal was to reach faster decisions that minimise outage duration and better decisions that prolong the turbine service life by several years. Within the UIW-project, Cluster \#1 developed a system that integrates $3 \mathrm{D}$ visualisation of the turbine with all inspection related data. From the upgrade process point of view, this tool is combining original design data with data from the equipment in use in order to enable efficient decision-making on what needs to be done to ensure continuous operation of the power plant.

Cluster \#4 is focused on developing applications to store technical information of the production system and improving current work activities centred in a collaborative view. Through the system developed in the UIW-project, measurement data collected with a 3D laser scanner and CAD data of the production cell can be combined. The goal is to improve the communication between the actors from different departments in order to make technical decisions using this information. In the UIW-project Cluster \#4 tested the system in an industrial setting supporting the decision-making of different actors in the manufacturing change/upgrade process. The test was based on a 3D laser scan of a part of the manufacturing which was due for an upgrade. The users were able to see the cell as-is in the first phase and then in the concept design phase they were able to visually compare alternative design solutions for the upcoming change.

\title{
3 Comparing the Business Models
}

In this chapter, we look at some common challenges related to the development and implementation of the four business models as well as some differences between these models.

\subsection{Common Features and Challenge in Implementation of Business Models}

\begin{abstract}
All cluster cases in the UIW-project focused on developing existing customer relationships and the main focus of all OEMs in the clusters is on the customers owning original equipment produced by them. This forms the market basis for their upgrade business activities. Building a confidential relationship with a customer is an investment of time and effort, and it should be re-utilised as far as possible. This is true for all the business models. As the designer of the original machines, equipment or systems, the OEM possesses the information on how it was originally designed and built. This is also an asset for reuse. In practice, introducing a service business into an OEM organisation is not straightforward. There are challenges
\end{abstract}


related to identification of the present owners of previously delivered products, understanding the upgrading needs of the customer, defining the state of the machine or system in operation, etc.

In general, we can say that the roles of the actors in the upgrade business are different from the roles these companies have in original equipment production. Upgrade projects are typically smaller in scope and shorter in duration than the original equipment production, and the original business processes are most likely not suitable for handling these new types of upgrading projects. Despite this difference to the original manufacturing process, the OEMs are in a central position in most of the upgrade business models presented in this chapter. Only in the Service Upgrade cases are the OEMs of the equipment not involved.

In all cluster cases in the UIW-project, the customer of the OEM is the owner and user of the equipment. In all but one case, this is an external party. Only in Cluster \#4, the customer is internal - a separated department within the same company. In four of the cluster cases, the providers of the upgrade services are OEM companies responsible for designing and manufacturing the original equipment. They have a good understanding of the technology and how it works, and based on this they provide solutions to new customer needs emerged after the original piece of equipment was delivered. This is their competitive advantage as upgrade service providers. The service activities are also, in general, based on existing customer relationships.

A common challenge for most of the Cluster cases and to the business models relates to the role of the new service business as part of the company's overall business portfolio. To some of the companies in the UIW-project introducing an upgrade service meant adding a new service to the existing portfolio of services. To others it was more a question of improving on existing services. Although the objective of adding a new service is improved customer service and increased sales, the introduction of the new life cycle service is also connected with a sense of risk that it might endanger the success of existing business activities. The synergy (or sometimes the lack thereof) between the old and the new activities affects how the companies can benefit from introduction of new upgrade business activities.

For the customer or the user of the equipment, the introduction of an upgrade service offers a new alternative means of ensuring the continuity, quality and competitiveness of their activities and the use of the equipment in their possession. An alternative would be to buy completely new equipment specially built for or originally constructed more suitable for the new situation. For the OEM, finding a balance between original equipment production and upgrade life cycle services is a central challenge when considering entering the upgrade business. Defining the scope of the upgrades and the upgrade business, as well as, pricing of upgrades are important decisions in this phase. A sense of risk for cannibalising of existing business was discussed in several of the UIW-cluster. In this chapter, we have seen that prolonging the lifetime of a boat - a central goal of the circular economy business models described earlier in this chapter - is from an economic point of view not trivial for the companies. In the simulated scenario, OCEAN - the boat manufacturing company — generally benefits from a reduced boat lifetime, but this 
was not true for all situations. Additionally, the boat operator Seability seems to profit from a shorter life cycle, which can be considered counterintuitive.

Based on the analysis of the Cluster cases, we identified three areas of cost control through the creation of efficient business processes. These areas are:

(1) reuse of resources and components

(a) original equipment as market base

(b) materials and components

(2) developing dedicated resources and service infrastructure,

(a) business network for upgrade production

(b) service equipment as business platform

(3) streamlining processes through improvement in information management and communication

\subsection{Main Differences Between Business Models}

A primary distinguishing factor between the business models is the clear difference in the value proposition offered. While the Customised Upgrade focuses on uniqueness and customisation, the Modular Upgrade s owners of old equipment to reach leading edge performance level typically offered by new equipment through as a low-cost alternative. Remanufacturing offers sustainability as its main value proposition. Service Upgrade is as such not a novel business model, but an improvement on an existing life cycle service.

We can also see some differences between the roles of the OEMs in the different business models. While they are not heavily involved in the Service upgrade cases, they are at the centre of the three other business models. Here again there are some differences in what roles they manage in-house and what they can outsource. Based on the UIW-cluster cases, it seems that in the Customised Upgrade and Remanufacturing business models the OEM performs all major activities in-house and outsource only highly specialised tasks. In the Modular Upgrade network, partners can play a central role also in the realisation and delivery of the upgrade service.

In Table 2, we have summarised the main features of the four upgrade business models. 
Table 2 Upgrade business models

\begin{tabular}{|c|c|c|c|c|}
\hline $\begin{array}{l}\text { Business } \\
\text { model }\end{array}$ & $\begin{array}{l}\text { Customized } \\
\text { upgrade }\end{array}$ & Modular upgrade & Remanufacturing & Service upgrade \\
\hline $\begin{array}{l}\text { Value } \\
\text { proposition }\end{array}$ & $\begin{array}{l}\text { Enables } \\
\text { equipment owners } \\
\text { or users to capture } \\
\text { unique, } \\
\text { innovative } \\
\text { business } \\
\text { opportunities } \\
\text { through an } \\
\text { upgrade service } \\
\text { tailored to their } \\
\text { needs. Increased } \\
\text { sustainability in } \\
\text { use of original } \\
\text { equipment can be } \\
\text { part of added } \\
\text { customer value }\end{array}$ & $\begin{array}{l}\text { Provided } \\
\text { equipment } \\
\text { owners or users } \\
\text { leading edge } \\
\text { performance } \\
\text { through } \\
\text { predefined and } \\
\text { productised } \\
\text { modular } \\
\text { upgrading of their } \\
\text { used equipment. } \\
\text { Increased } \\
\text { sustainability in } \\
\text { the use of original } \\
\text { equipment can be } \\
\text { part of added } \\
\text { customer value }\end{array}$ & $\begin{array}{l}\text { Providing } \\
\text { sustainable } \\
\text { equipment } \\
\text { designs through } \\
\text { reuse of } \\
\text { component from } \\
\text { used/existing } \\
\text { equipment }\end{array}$ & $\begin{array}{l}\text { Providing } \\
\text { equipment } \\
\text { owners unique, } \\
\text { productised and } \\
\text { digitally } \\
\text { supported } \\
\text { services to } \\
\text { improve } \\
\text { utilisation of } \\
\text { capital-intensive } \\
\text { equipment and to } \\
\text { enhance } \\
\text { end-customer } \\
\text { service. Increased } \\
\text { sustainability in } \\
\text { the use of } \\
\text { original } \\
\text { equipment can be } \\
\text { part of customer } \\
\text { value }\end{array}$ \\
\hline $\begin{array}{l}\text { Market base } \\
\text { and } \\
\text { customers }\end{array}$ & $\begin{array}{l}\text { Original } \\
\text { equipment in use } \\
\text { and its } \\
\text { owners/users }\end{array}$ & $\begin{array}{l}\text { Original } \\
\text { equipment in use } \\
\text { and its } \\
\text { owners/users }\end{array}$ & $\begin{array}{l}\text { Reusable } \\
\text { components of } \\
\text { original } \\
\text { equipment in use }\end{array}$ & $\begin{array}{l}\text { Original } \\
\text { equipment in use } \\
\text { and its } \\
\text { owners/users }\end{array}$ \\
\hline $\begin{array}{l}\text { Upgrade } \\
\text { task }\end{array}$ & $\begin{array}{l}\text { Upgrading parts } \\
\text { of the original } \\
\text { equipment to } \\
\text { meet new } \\
\text { purposes of use }\end{array}$ & $\begin{array}{l}\text { Adding upgrade } \\
\text { module or } \\
\text { replacing existing } \\
\text { module with } \\
\text { upgraded module }\end{array}$ & $\begin{array}{l}\text { Reusing } \\
\text { components of } \\
\text { original } \\
\text { equipment in new } \\
\text { products }\end{array}$ & $\begin{array}{l}\text { Information } \\
\text { management to } \\
\text { support upgrade } \\
\text { and other service } \\
\text { activities }\end{array}$ \\
\hline $\begin{array}{l}\text { Key actors } \\
\text { and roles }\end{array}$ & $\begin{array}{l}\text { Customer: } \\
\text { equipment owner, } \\
\text { initiator of } \\
\text { upgrade process, } \\
\text { purchaser of } \\
\text { upgrade service } \\
\text { OEM: fleet } \\
\text { management, } \\
\text { CRM, upgrade } \\
\text { provider, } \\
\text { engineering, } \\
\text { manufacturing, } \\
\text { development of } \\
\text { upgrade business } \\
\text { process } \\
\text { Service provider: } \\
\text { provider of } \\
\text { outsourced expert } \\
\text { services }\end{array}$ & $\begin{array}{l}\text { Customer: } \\
\text { equipment owner, } \\
\text { purchaser of } \\
\text { upgrade service, } \\
\text { OEM: fleet } \\
\text { management, } \\
\text { CRM, upgrade } \\
\text { provider, R\&D, } \\
\text { product } \\
\text { development, } \\
\text { productisation, } \\
\text { development of } \\
\text { upgrade business } \\
\text { process } \\
\text { Service } \\
\text { provider: as-is } \\
\text { data collection, } \\
\text { upgrade delivery } \\
\text { and installation, }\end{array}$ & $\begin{array}{l}\text { Customer: } \\
\text { equipment owner, } \\
\text { purchaser of } \\
\text { remanufactured } \\
\text { equipment } \\
\text { OEM: designer } \\
\text { and producer of } \\
\text { original } \\
\text { equipment, } \\
\text { designer and } \\
\text { producer of } \\
\text { remanufactured } \\
\text { equipment, } \\
\text { reverse logistics, } \\
\text { Researchers: } \\
\text { developing and } \\
\text { testing of } \\
\text { innovative digital } \\
\text { technology, }\end{array}$ & $\begin{array}{l}\text { Customer: } \\
\text { equipment } \\
\text { owner, purchaser } \\
\text { of improved } \\
\text { service } \\
\text { Service } \\
\text { provider: } \\
\text { provider of } \\
\text { improved } \\
\text { service, service } \\
\text { process } \\
\text { development, } \\
\text { testing and } \\
\text { implementation } \\
\text { of innovative } \\
\text { digital tools } \\
\text { Researchers: } \\
\text { developing and } \\
\text { testing of }\end{array}$ \\
\hline
\end{tabular}


Table 2 (continued)

\begin{tabular}{|c|c|c|c|c|}
\hline $\begin{array}{l}\text { Business } \\
\text { model }\end{array}$ & $\begin{array}{l}\text { Customized } \\
\text { upgrade }\end{array}$ & Modular upgrade & Remanufacturing & Service upgrade \\
\hline & $\begin{array}{l}\text { Technology } \\
\text { provider: } \\
\text { provider of digital } \\
\text { tools, technology } \\
\text { development and } \\
\text { manufacturing } \\
\text { Researchers: } \\
\text { developing and } \\
\text { testing of } \\
\text { innovative digital } \\
\text { technology, } \\
\text { supporting } \\
\text { business model } \\
\text { transformation }\end{array}$ & $\begin{array}{l}\text { management of } \\
\text { upgrade process, } \\
\text { testing and } \\
\text { implementation } \\
\text { of innovative } \\
\text { digital tools } \\
\text { Researchers: } \\
\text { developing and } \\
\text { testing of } \\
\text { innovative digital } \\
\text { technology, } \\
\text { supporting } \\
\text { business model } \\
\text { transformation }\end{array}$ & $\begin{array}{l}\text { supporting } \\
\text { business model } \\
\text { transformation }\end{array}$ & $\begin{array}{l}\text { innovative digital } \\
\text { technology, } \\
\text { supporting } \\
\text { business model } \\
\text { transformation }\end{array}$ \\
\hline $\begin{array}{l}\text { Earnings } \\
\text { logic }\end{array}$ & $\begin{array}{l}\text { Improved sales } \\
\text { through } \\
\text { innovative } \\
\text { capturing of } \\
\text { customer needs } \\
\text { and value } \\
\text { Dedicated } \\
\text { upgrade service } \\
\text { infrastructure and } \\
\text { resources } \\
\text { Integrated } \\
\text { information } \\
\text { management in } \\
\text { business network } \\
\text { Value-based } \\
\text { pricing }\end{array}$ & $\begin{array}{l}\text { Improved } \\
\text { customer loyalty, } \\
\text { Added turnover } \\
\text { per customer, } \\
\text { Productised } \\
\text { modular upgrade } \\
\text { services } \\
\text { Dedicated } \\
\text { upgrade service } \\
\text { network and } \\
\text { resources } \\
\text { Focusing } \\
\text { in-house product } \\
\text { development } \\
\text { efforts on } \\
\text { innovative } \\
\text { modules and } \\
\text { product features }\end{array}$ & $\begin{array}{l}\text { Providing } \\
\text { customer with } \\
\text { sustainable } \\
\text { equipment based } \\
\text { on reused } \\
\text { components } \\
\text { Control of market } \\
\text { base } \\
\text { Reverse logistics } \\
\text { process } \\
\text { Remanufacturing } \\
\text { process }\end{array}$ & $\begin{array}{l}\text { Improved } \\
\text { customer loyalty } \\
\text { through } \\
\text { improved service } \\
\text { performance } \\
\text { Improved } \\
\text { productivity of } \\
\text { service work } \\
\text { Value-based } \\
\text { pricing }\end{array}$ \\
\hline $\begin{array}{l}\text { Cluster } \\
\text { cases in } \\
\text { UIW-project }\end{array}$ & $\begin{array}{l}\text { Cluster \#3 } \\
\text { Cluster \#5 }\end{array}$ & Cluster \#2 & Cluster \#6 & $\begin{array}{l}\text { Cluster \#1 } \\
\text { Cluster \#4 }\end{array}$ \\
\hline
\end{tabular}

\subsection{Similarities and Differences in Information Management}

Since the focus of the UIW-project was on information management in the upgrade business, we will look more closely at the similarities and differences between the pilot solutions developed for the different business models in order to see if we can identify special information management challenges related to these business models. The pilots are listed in Table 3. 
Table 3 Information management pilots in the UIW-project

\begin{tabular}{|c|c|c|c|}
\hline Business model & $\begin{array}{l}\text { Cluster } \\
\text { case }\end{array}$ & Pilot & $\begin{array}{l}\text { Abbreviation } \\
\text { (see Fig. 5) }\end{array}$ \\
\hline \multirow[t]{2}{*}{$\begin{array}{l}\text { Customised } \\
\text { upgrade }\end{array}$} & $\begin{array}{l}\text { Cluster } \\
\# 3\end{array}$ & $\begin{array}{l}\text { Reference data model } \\
\text { Request Web Configurator } \\
\text { Web environment }\end{array}$ & $\begin{array}{l}\text { CU1 } \\
\text { CU2 } \\
\text { CU3 }\end{array}$ \\
\hline & $\begin{array}{l}\text { Cluster } \\
\# 5\end{array}$ & $\begin{array}{l}\text { Reference data model } \\
\text { Vessel configuration tool }\end{array}$ & $\begin{array}{l}\text { CU4 } \\
\text { CU5 }\end{array}$ \\
\hline Modular upgrade & $\begin{array}{l}\text { Cluster } \\
\# 2\end{array}$ & $\begin{array}{l}\text { Testing of 3D scanning technologies } \\
\text { AR-based review tool }\end{array}$ & $\begin{array}{l}\text { MU1 } \\
\text { MU2 }\end{array}$ \\
\hline Remanufacturing & $\begin{array}{l}\text { Cluster } \\
\# 6\end{array}$ & Circular design framework & RM1 \\
\hline \multirow[t]{2}{*}{ Service upgrade } & $\begin{array}{l}\text { Cluster } \\
\# 1\end{array}$ & $\begin{array}{l}\text { Webb app for managing inspection results } \\
\text { using 3D environment. }\end{array}$ & SU1 \\
\hline & $\begin{array}{l}\text { Cluster } \\
\# 4\end{array}$ & $\begin{array}{l}\text { Combination of measurement data } \\
\text { collected with a 3D laser scanner and CAD } \\
\text { data of the production cell }\end{array}$ & SU2 \\
\hline
\end{tabular}

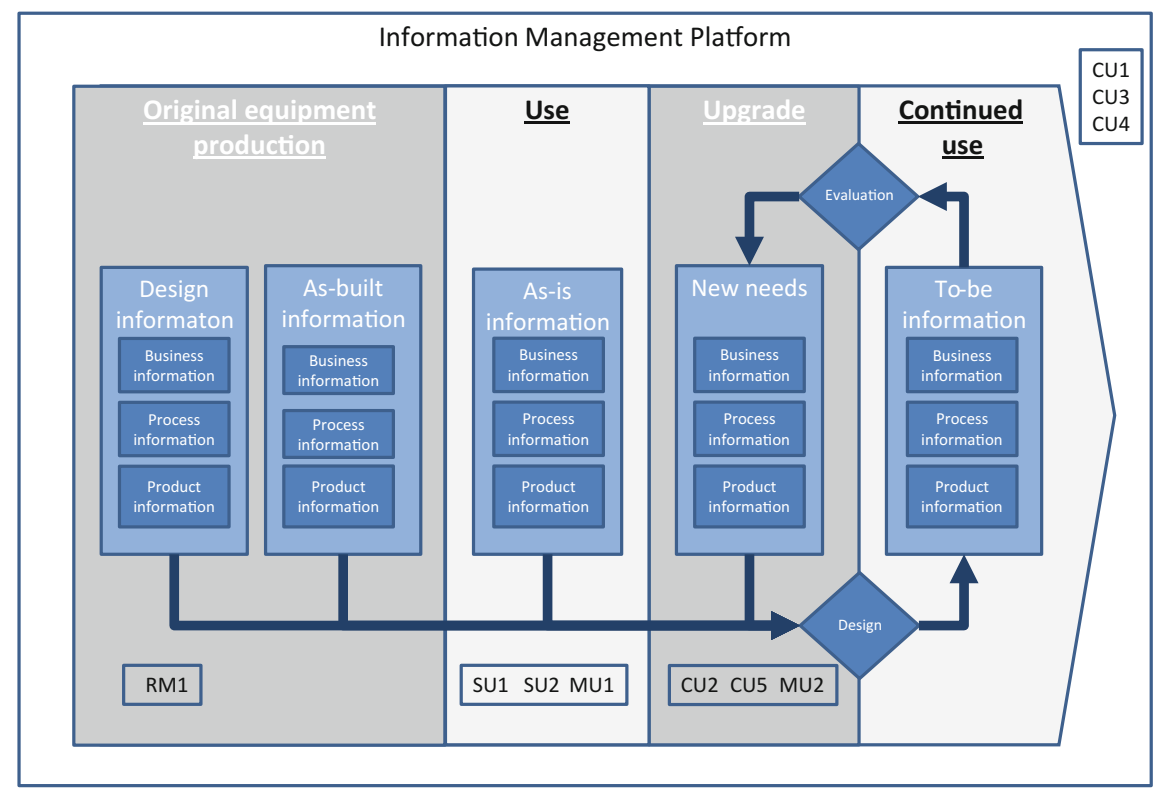

Fig. 5 Upgrade information management process

In Fig. 5, we have described a rough model for information management in the upgrade business. The starting point is the original equipment production and the design data created in this phase. In this model, we have divided the information in business-related data or information, process-related information and product 
information. While product data and information is stored in formal formats in CAD and PLM systems, process information and business information can take a variety of forms and the quality and completeness of stored data varies.

Designed information: reusing the original design information is a central factor in the business model of upgrading. This information is stored in the OEM's archives in different formats. Today, most of it is in electronic format, but for very old equipment or systems there may still be a need to look for this information on paper. Additionally, the electronic formats have changed over the year, so making use of old information might require updating the information to a newer format.

As-built information: in complex products like machinery and equipment there are often steps that are not documented fully during the design process. This so called as-built information is not always documented, but modern means like digital cameras have for some time been used to document this information.

Use-information: during the use of the equipment, changes are made for several reasons. Worn out or broken components are replaced, smaller or larger additions or upgrades are made, etc. Often these types of changes are not documented, or some of the information can be stored by the organisation responsible for the changes. In order to perform an upgrade, as-is information is often needed, and needs to be collected in one way or another. Formally stored information can be requested from the user or other actors, or information can be created from scratch.

Upgrade need information: the need for an upgrade can emerge from several root causes. It can be a change in the business environment of the user of the original equipment which triggers the need, or the user might have seen something similar somewhere else. Depending on how this need emerges, the initial idea can be more or less abstract and the solution might require more or less work. When the initial idea is abstract, several iterations between users, engineers and the production team can be needed before a solution acceptable for all parties is found.

To-be information: this is the data and information produced based on prior information, re-created information and new information. This information needs to be stored, maintained and managed for further use during the life cycle of the machine or equipment.

Twelve pilot demonstrations were made in UIW. Of these, ten are mapped on the upgrade process in Fig. 2. Two demonstrations focus on the business modelling in Cluster cases \#5 and \#6. These are not included in this analysis.

In Fig. 5, we see that the new tools and solutions developed in the UIW-project are focusing on four different areas in the upgrade process. First, we can see that two clusters have developed tools and methods for general information management in the upgrade process. Secondly, one group of tools developed by the clusters focuses on creating and evaluating information on new customer needs. Thirdly, three clusters have focused on as-is information; creating it through 3D-scanning, combining it with original design data and visualising it to support dialogue and decision-making among several actors involved in the process. Fourthly, one cluster focuses on the original equipment design process. 


\subsubsection{Pilots for Customised Upgrade}

The tools and methods in the first area developed for general information management can be divided into two categories; one is the creation of a reference data model - a meta-file - for storing and managing all the life cycle information of the machine to be upgraded. The information stored concerns a specific piece of equipment, not a machine type or class. Without this system, the information is scattered around in the network of actors or even non-existing in formal sense. The second category of tools and methods in this group is the communication infrastructure between independent actors in the business network for the management of common meta-files. The meta-files and communication network tools were in the UIW-project developed especially by Cluster \#3 and \#5, and although similar tools can also be useful in other upgrade business models, the need for collecting and managing information on single customer needs and for transforming this information into new upgrade solutions makes a tool like this crucial in this business model.

The second area of tools development in the UIW-project focused on creating and evaluating information on the new needs of the single customer looking for an upgrade. This is crucial in the cases of customised upgrading. Understanding the needs of the customer, documenting it and evaluating it with different stakeholders is an essential part of the upgrading process. Mistakes in this phase of the process mean that everything done before the mistake is realised has to be reconsidered and possibly redone, and this costs both time and money. In both the Italian and the Greek cluster cases, the focus is both on documenting the customer's initial ideas for the upgrade, but also on evaluating and comparing different upgrade design solutions with the customer's needs and ideas.

\subsubsection{Pilots for Modular Upgrade}

In the Modular Upgrade business model, a great deal of information is dealt with internally by the OEM, and the special development needs were found in the customer interface in the management of as-is information. This represents the third area of tool development in the UIW-project. Comparing it with original design information and visualising the changes that have taken place in the equipment during use support dialogue and decision-making in a network of actors planning and designing the upgrade solution for the customer. Creating digital as-is information is essential in situations where this information does not exist or is not available to the actors performing the upgrade. In the Metso case, the machines have typically been in use for years and the user might have made changes to the machine without systematic documentation. 3D models of the used equipment were in Cluster \#2 created using a set of 3D scanning techniques. 
Also the evaluation of upgrade design solutions was considered important in Cluster \#2. Here the focus was, however, more on visualisation for engineers and customers of how a predefined upgrade module would fit the customer's machine and to demonstrate how it would function with the new upgrade. To do this, virtual design reviews were held in a virtual reality environment that also made use of augmented reality solutions.

\subsubsection{Pilots for Remanufacturing}

The fourth area addressed in the development of the tools and methods in the UIW-project bring into focus the design of original equipment. As we saw earlier, Gispen focused on developing a circular economy Design Framework and demonstrated the use of a checklist for circular product design. This list was used for evaluating how well original equipment designs supported remanufacturing and circular design. In this case, the market base consists of re-usable components of furniture available and fit for recycling. The better the recycling already planned in the original design phase, the faster the market base of recyclable components will grow and the bigger the market base will become.

\subsubsection{Pilots for Service Upgrade}

The Service Upgrade pilots can be divided into two groups. First, one pilot focuses on creating the as-is information in an environment including several machines and equipment as well as infrastructure, in this case the building. The second pilot in this group documents and presents data on what has been done during maintenance of equipment.

In Cluster \#4, as-is information of the Volvo factory is created through 3D scanning. In this case the object - the factory - consists of a wide range of equipment, the building, products, components, material, etc. Original information on the building or equipment can exist in a digital format, but most likely scanning the necessary information is faster than collecting original data from external sources.

In Cluster \#1, a software tool is storing information on inspection and testing tasks, procedures and plans, information on results of inspections, as well as 2D drawings of the inspected equipment. A 3D model based on the 'as-is' turbine was created after 3D scanning the turbine. This 3D model is used to visualise the turbine and the inspection results in order to easily understand the overall situation and allow for the decision making of the stakeholders to take place in a collaborative manner and with all of the necessary information. 


\section{Conclusions}

In this chapter, we have described four generic upgrade business models based on the six industrial Cluster cases in the UIW-project. These business models provide opportunities for producers of capital-intensive goods or equipment to strengthen the contact with their customers and to provide the customer valuable services aimed at improving their competitiveness under changing market conditions. The four business models all provide their own, specific added value for the customer. These business models can be added as part of the life cycle service portfolio in a company, but some of the business models can also have the potential to achieve more profound changes in how manufacturing companies operate in the future. For instance, remanufacturing has the potential to take manufacturing into a new cycle of material and energy flow, where existing physical parts become the raw material for the production of similar or even totally new products. Modular Upgrade can revolutionise how we see the connection between innovation and the product life cycle.

In the analysis of the business models, we realised that circular economy drivers were present in most of the cluster cases, but not necessarily in the way that they have been presented in academic work. Closing the material loop (Bocken et al. 2016) and thus, providing the customer more sustainably produced products was a driver mainly in the Remanufacturing case of Gispen in Cluster \#6. Prolonging the loops (Bocken et al. 2016) was considered a challenge or even risk for the OEM companies in Clusters \#2 and \#5. Instead, these companies offered more sustainable operation of the original equipment as an added value for the customer. This can enable the customer to perform business activities in areas of high sustainability standards.

To the companies in the clusters, the upgrade business provides opportunity for added sales and turnover through the addition of new customer offerings, or through improvement in or replacement of existing services. To the OEMs providing upgrade services, it is also a means of improving the competitive edge in the original equipment market.

We also learned that, while providing existing customers with upgrade services can improve sales, profitable execution of this business requires efficient management of the business processes. While the circular economy business models focus on the reuse of finite or renewable materials, the business model used in the cluster cases are all centred on what could be called reuse of intangible resources. Development or strengthening of the long-term customer-supplier relationship was the main objective in most of the UIW-clusters. To the users of the equipment, prolonging of the economic life cycle of the equipment is a central objective, but to the OEM companies, this plays a secondary role. Among the companies in the six clusters, only Gispen was looking to directly close the material loop through remanufacturing. 
The second means in creating efficient processes in the cluster cases was the use of dedicated resources. While the object of the upgrade activity is the same as in original equipment manufacturing, the process is not the same. Upgrading results in limited changes to the equipment and is thus a separate process. Depending on the case, the roles in the upgrade network can be managed in-house or by external partners. Dedicating special resources for upgrading activities gives a stronger focus to both the original equipment manufacturing and the upgrade activities.

Thirdly, the role of information management is emphasised in the upgrade value network since detailed information has to be collected from several sources using several different means. From the cluster cases, we identified four areas where modern information technology can improve information management in the upgrade business process. Firstly, it helps to create as-is information on equipment in use in, and in comparison to, this information with information from the original equipment design and production. Secondly, it can be helpful in creating, documenting and evaluating the upgrade needs of the customers or users. Being able to do virtual tests on new design solutions with the customer needs in a virtual environment is a central means for reducing iterations during design and implementation of the customer-specific upgrade.

Fourth, there is a need to consider upgrade business issues already in the original equipment design and manufacturing. This was demonstrated in the remanufacturing case of Gispen, but it will most likely also be of importance in cases of modular upgrading, where the feature of the product is upgraded by adding or changing specific modules.

Fifth and finally, upgrading is, by its nature, a process of information management in a networked environment. Joint information management and information sharing are crucial for the success of the upgrade business and, therefore, a common information management platform plays a central role in these activities. A central focus of the UIW-project was initially on technologies like VR and AR. These technologies are used for visualisation of electronically stored data. The work done in the UIW-project shows that there are several areas in the upgrade process where visualisation of information is needed. Visualisation of data and information can be a means to get a better understanding of three-dimensional models used for planning upgrades, and as such it can be a means for people of different backgrounds to communicate whit each other about the upgrade. These are central means in developing a dynamic upgrade process where data is collected from several sources and several actors have to understand and approve it.

A final conclusion of the findings from the UIW-project is that, although there are signs of the growing importance of environmental sustainability in the activities of companies in the durable goods area, in most cases the main objectives driving the companies to adopt upgrade business are still in line with more traditional service business objectives. Sustainability becomes a driver in business as a demand 
for sustainable products develops. This can be clearly seen in the crusher market in Cluster \#2 and the boat market of Cluster \#5. The different cycles in the circular economy will also compete with each other. Recycling of materials is already a huge business and for some raw materials like copper, a significant part of the material is already recycled (European Copper Institute 2016). Thus, upgrading is not only competing with virgin materials, but with recycled materials and from an environmental point of view, the benefit of using upgrades is the prolonging of the cycle. For the OEM companies the role of upgrading business alongside the original equipment manufacturing will change as margins from upgrading outperforms margins of original equipment manufacturing. In this situation, production of new equipment aims mainly at growing the market base for upgrading. In remanufacturing, the difference from recycling is the saving of energy as part are reused without heavy processing.

For OEM companies focusing on original equipment manufacturing changing to an upgrade business model based on ownership of the equipment, major changes in the capital structure are required. Building and owning the original equipment absorbs huge capital, while inbound cash flows will initially be low and gradually increase as business grows. In many companies, especially SMEs, these changes are likely to require renewal of the funding structure and possibly also the ownership of the company.

\section{References}

Allwood, J. M., Ashby, M. F., Gutowski, T., \& Worrell, E. (2011). Material efficiency: A white paper. Resources, Conservation and Recycling, No 55. pp. 362-381.

Bocken, N. M., De Pauw, I., Bakker, C., \& van der Grinten, B. (2016). Product design and business model strategies for a circular economy. Journal of Industrial and Production Engineering, 33(5), 308-320. http://dx.doi.org/10.1080/21681015.2016.1172124

Ellen MacArthur Foundation. (2016). Circular economy system diagram. Retrieved May 31, 2016, from https://www.ellenmacarthurfoundation.org/circular-economy/interactive-diagram

European Copper Institute. (2016). Resources: The sources of copper. Retrieved September 29, 2016, from http://copperalliance.eu/about-copper/resources

Lacy, P., \& Rutqvist, J. (2015). Waste to wealth : The circular economy advantage. Basingstoke, GB: Palgrave Macmillan. ProQuest ebrary. Web. 31 May 2016

Linton, J. D., \& Jayaraman, V. (2005). A framework for identifying differences and similarities in the managerial competencies associated with different modes of product life extension. International Journal of Production Research, 43, 1807-1829.

Osterwalder, A., \& Pigneur, Y. (2010). Business model generation. A handbook for visionairies, game changers, and challengers. New Jersey: Wiley.

Pasquinelli, A., Chico, L., Pasquali, L., Bisordi, C., Lo Gerfo, A., Fabbrini, M., et al. (2016). Gly482Ser PGC-1alpha gene polymorphism and exercise-related oxidative stress in amyotrophic lateral sclerosis patients. Front Cell Neuroscience (April), 10, 102. https://doi.org/10. 3389/fncel.2016.00102 
Roos, G., \& Agarwal, R. (2015). Services innovation in a circular economy. In R. Agarwal et al. (Eds.), The handbook of service innovation. London: Springer.

Stahel, W. R. (2016). Circular economy. A new relationship with our goods and materials would save resources and energy and create local jobs. Nature, 03/2016, 531(7595), 435-438.

Open Access This chapter is licensed under the terms of the Creative Commons Attribution-NonCommercial 4.0 International License (http://creativecommons.org/licenses/by-nc/ $4.0 /)$, which permits any noncommercial use, sharing, adaptation, distribution and reproduction in any medium or format, as long as you give appropriate credit to the original author(s) and the source, provide a link to the Creative Commons license and indicate if changes were made.

The images or other third party material in this chapter are included in the chapter's Creative Commons license, unless indicated otherwise in a credit line to the material. If material is not included in the chapter's Creative Commons license and your intended use is not permitted by statutory regulation or exceeds the permitted use, you will need to obtain permission directly from the copyright holder.

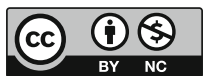

